\title{
Associated features in females with an FMR1 premutation
}

\author{
Anne C Wheeler ${ }^{1,9^{*}}$, Donald B Bailey Jr ${ }^{1}$, Elizabeth Berry-Kravis ${ }^{2}$, Jan Greenberg ${ }^{3}$, Molly Losh ${ }^{4}$, Marsha Mailick ${ }^{3}$, \\ Montserrat Milà ${ }^{5}$, John M Olichney ${ }^{6,8}$, Laia Rodriguez-Revenga ${ }^{5}$, Stephanie Sherman ${ }^{7}$, Leann Smith ${ }^{3}$, \\ Scott Summers ${ }^{6,8}$, Jin-Chen Yang ${ }^{6,8}$ and Randi Hagerman ${ }^{6,8}$
}

\begin{abstract}
Changes in the fragile $X$ mental retardation 1 gene (FMR1) have been associated with specific phenotypes, most specifically those of fragile $X$ syndrome (FXS), fragile $X$ tremor/ataxia syndrome (FXTAS), and fragile $X$ primary ovarian insufficiency (FXPOI). Evidence of increased risk for additional medical, psychiatric, and cognitive features and conditions is now known to exist for individuals with a premutation, although some features have been more thoroughly studied than others. This review highlights the literature on medical, reproductive, cognitive, and psychiatric features, primarily in females, that have been suggested to be associated with changes in the FMR1 gene. Based on this review, each feature is evaluated with regard to the strength of evidence of association with the premutation. Areas of need for additional focused research and possible intervention strategies are suggested.
\end{abstract}

Keywords: fragile X, FMR1 premutation, health risks

\section{Review}

The fragile $\mathrm{X}$ mental retardation 1 (FMR1) gene was discovered in 1991, and named as such for its role as the causative gene for fragile X syndrome (FXS) [1-3]. Over the last two decades since its discovery, significant advances have been made in understanding the phenotypic expressions of mutated FMR1 alleles. The primary mutation known to cause FXS results from an expansion of a cytosine-guanine-guanine (CGG) trinucleotide repeat sequence in the first exon and promoter of FMR1. The repeat sequence is located in the $5^{\prime}$ untranslated region of the FMR1 mRNA, and thus is not translated and does not affect the sequence or structure of its encoded product, the Fragile X Mental Retardation Protein (FMRP). Normal alleles are considered to have between 5 and 44 CGG repeats, alleles with 45 to 54 repeats are intermediate or 'gray zone', 55 to 200 repeats constitute a 'premutation' and 200 or more repeats, a 'full mutation'.

\footnotetext{
* Correspondence: acwheeler@rti.org

${ }^{1}$ RTI International, 3040 Cornwallis Road, Research Triangle Park, NC 27709, USA

${ }^{9}$ Carolina Institute for Developmental Disabilities, University of North Carolina at Chapel Hill, Chapel Hill, NC 27599, USA

Full list of author information is available at the end of the article
}

An individual with a full mutation is considered to have FXS, which results from hypermethylation of the promoter, silencing of the FMR1 gene and subsequent decrease or absence of production of FMRP, which is necessary for healthy brain maturation. The phenotype of FXS includes intellectual disability (ID), hyperarousal, social difficulty, anxiety, aggression, and autism spectrum disorder (ASD) or autism traits [4]. The FXS phenotype is not described in detail here; however, literature on the impact of the challenging behavioral characteristics of FXS on family members with a premutation is included where applicable.

The premutation was historically thought to be associated only with risk for instability in the gene from generation to generation, and for children or grandchildren with FXS, and not to specifically mediate disease in the premutation 'carriers' themselves. However, research on the premutation phenotype over the last 10 to 15 years has demonstrated clear health risks associated with FMR1 expansions in the premutation range. Two known disorders - fragile X-associated primary ovarian insufficiency (FXPOI) and fragile X-associated tremor/ataxia syndrome (FXTAS) have now been well documented $[5,6]$. These conditions are known to exist in a subset of individuals with a premutation, with specific associated 
symptoms and trajectories. Several additional medical, emotional and cognitive challenges have also been described as occurring at a greater frequency among individuals with a premutation than would be expected in the general population, although the association of the premutation with many of these conditions is less well established. Why some individuals with the premutation are unaffected and others have symptoms may relate to a number of factors, including the CGG repeat length, magnitude of elevation of toxic CGG repeat-containing FMR1 mRNA. Also possibly implicated are antisense FMR1 transcripts, low FMRP levels, (particularly in the upper premutation range), byproducts of aberrant translation of the repeat sequence including polyglycinecontaining peptides, genomic changes in the rest of the genome, and environmental factors including toxins or other exposures that may be harmful to the brain and stress in families with fragile $\mathrm{X}$ associated disorders. There is a suggestion of a continuum of involvement with mild anxiety or shyness in some children or adults with the premutation to more severe psychiatric problems and as carriers age, appearance of neurological problems that may eventually result in FXTAS [6].

Understanding the phenotype associated with the premutation is important from a public health perspective, given its prevalence. In the three US population-based studies of the prevalence of CGG expansions, a higher prevalence was observed than previously reported (1 in 151 women and 1 in 468 men [7]; 1 in 209 women and 1 in 430 men [8]; 1 in 148 women and 1 in 290 men [9]. This prevalence translates into over 1 million premutation carriers in the United States. The world literature reveals considerable ethnic variability of prevalence of the premutation, ranging in males from 1 in 1,674 in Japan to 1 in 251 in Spain, and in females from 0 detected in 324 tested cases in Japan to 1 in 113 in Israel (reviewed in [7])

This paper provides a review of features described in the literature as being more prevalent in individuals, especially females, with a premutation. We approach this review with a focus primarily on features seen outside of the known diagnoses of FXS, FXTAS, and FXPOI, in order to identify additional conditions that may be directly associated with an FMR1 expansion; however, we compare the relative strength of evidence for each feature among those with and without FXTAS or FXPOI in the tables. As there is more literature describing these features in females, we focus primarily on women; however, where mixed gender studies have been conducted, evidence of these features in males is also described. Similarly, we focus on the more extensive literature on adults with a premutation with reference where appropriate to studies that have included children. Where evidence or the suggestion of a relationship with CGG repeat length has been found, this relationship has been noted in the tables.

Based on the review of the literature and expert nominations from direct clinical experience, we describe medical, cognitive, and psychiatric features in females and rate each with the following criteria: 1) 'definitely related' indicating clear evidence of an association in unbiased or minimally biased groups of carriers relative to well-matched controls in several independent studies; 2) 'probably related' suggesting strong evidence of an association but either only one study, some conflicting evidence or a need for studies examining the broader population (for example, those not clinically ascertained); 3) 'possibly related' indicating emerging or anecdotal evidence of an association with more extensive research needed; or 4) 'not likely related' suggesting strong evidence of an absence of an association through direct examination. These ratings are not meant to be definitive; rather to assist in guiding future targeted research.

\section{Medical features \\ Immune mediated disorders}

A variety of medical problems besides FXTAS and FXPOI have been reported to occur more frequently in premutation carriers ascertained from clinical populations, as compared to noncarrier controls. Thyroid problems were found in $17.3 \%$ of non-FXTAS female carriers (not significantly different from controls), but in $50 \%$ of women with FXTAS, which was a significantly higher frequency than in age-matched controls [10]. A study of female carriers by Rodriquez-Revenga et al. [11] also found a significant increase in thyroid disease, as did results from a large national survey of female carriers [Wheeler, A.C, Bailey D.B., Raspa M., unpublished data]. Comparison between nonclinically referred premutation carriers and non-carriers ages 18 to 50 showed an increase to $10 \%$ from $5 \%$, but this was not statistically significant [12]. Thus, this association may be important in older women. Irrespective, these problems may include either a history of Hashimoto's thyroiditis leading to hypothyroidism or occasionally, Graves' disease. These problems are immune-mediated disorders (IMD) and they are one of several such problems that have been reported in female carriers [13]. Winarni et al. [13] studied 344 adult female carriers ascertained from fragile $\mathrm{X}$ families and found that $44.7 \%$ suffered from an IMD compared to $27.8 \%$ of controls. The odds ratio of having an IMD was significantly elevated both in females with FXTAS $(\mathrm{OR}=5.5)$ and without FXTAS $(\mathrm{OR}=2.1)$ from this cohort compared to controls [13]

\section{Fibromyalgia symptoms}

In the study of IMD [13], autoimmune thyroid disorders were the most common problems overall (24.4\%) followed 
by fibromyalgia in $10.2 \%$. Both of these were significantly different compared to a limited number of controls $(\mathrm{n}=72)$. However, two recent studies of FMR1 mutations among women with fibromyalgia in Spain have reported conflicting findings, with one study of 353 women finding an increased rate of FMR1 premutations, while a second study of 700 women did not find an association $[14,15]$. More research is needed in this area.

\section{Hypertension}

Hypertension was first noted by Coffey et al. [10] in a survey of 146 premutation female carriers ascertained from fragile $X$ families in clinic. In a large national survey of women with a premutation, $15.1 \%$ of women reported a diagnosis of hypertension, which was significantly lower than national occurrence rates [Wheeler, A.C, Bailey D.B., Raspa M., unpublished data]. Similarly, hypertension was seen in $16.4 \%$ of women without FXTAS which was not different from age-matched controls (10\%). However, hypertension was seen in $61 \%$ of females with FXTAS, a significantly higher frequency than $18 \%$, observed in agematched controls. Hypertension may be considered an autonomic problem associated with premutation-mediated toxicity related to FXTAS.

\section{Migraines}

Migraines are common among carriers and they occur in both males and females. In a single study of 315 carriers (203 females and 112 males) compared to 154 controls, a diagnosis of migraines was seen in $54.2 \%$ of female carriers, significantly different from female controls (25.3\%) [16]. Smith, Seltzer, and Greenberg [17] reported that headaches (not specifically migraines) were significantly more common among premutation carrier mothers of children with FXS (26.9\%) than matched controls $(13.6 \%)$ who did not have children with disabilities. Of note, headaches were not significantly increased in carriers ascertained from the general population compared to controls in Seltzer et al. [7], so this may imply a relationship between migraines in families ascertained in clinic and family stress issues. Migraines can be associated with some syndromes resulting from mitochondrial dysfunction, which has been observed in cell lines from premutation carriers $[18,19]$. As with the general population, the onset of migraines is typically in teenage or young adult years and migraine prevalence decreases with age [16].

\section{Neuropathy}

Neuropathy was first reported in female premutation carriers in a series of five case reports of females with FXTAS, of whom four had signs of neuropathy on examination [20]. In a subsequent neuropathological case series [21] of eight women with the premutation with or without FXTAS, three were noted to have neuropathy. One of these women had chemotherapy with multiple neurotoxic agents, making it difficult to determine whether the neuropathy related to the premutation, and one had multiple sclerosis with likely central symptoms complicating assessment of nerve disease. One of the women, however, did have neuropathy with no obvious cause other than the premutation.

Several studies have examined neuropathic signs and symptoms in large groups of carriers relative to controls. Berry-Kravis et al. [22] found a significantly higher numerical neuropathy score based on examinations of 73 female premutation carriers relative to 32 age-matched control women, but this finding did not achieve statistical significance. The neuropathy score correlated with CGG repeat length after controlling for activation ratio, suggesting a relationship of neuropathic signs to the premutation. Neuropathy scores also correlated with the ataxia subscore on the FXTAS rating scale, suggesting that carriers beginning to have signs of FXTAS are more likely to have neuropathic signs than those without signs of FXTAS. Coffey et al. [10] studied 128 female carriers without FXTAS, 18 carriers with FXTAS and 69 controls, and found a significant rate of numbness and tingling and muscle pain in the extremities in both women with FXTAS and also in those without FXTAS compared to controls. However, neurological examination showed there was rarely sensory loss or evidence of neuropathy in women without FXTAS. Evidence of neuropathy upon examination was increased in carriers with FXTAS as compared to controls and to carriers without FXTAS. Carrier women without FXTAS also reported a history of intermittent tremor in $11 \%$, significantly higher than the controls with $1.5 \%$ [10]. Therefore, symptoms of neurological problems by history are more common than what is documented by neurological examination, presumably because symptoms may be very intermittent early on and persistent findings only occur when the CNS changes are more significant. In Chonchaiya et al. [23], a structured questionnaire was administered to 110 female carriers who were daughters of a parent with FXTAS, 36 female carriers without a parent with FXTAS, and 43 controls. Neuropathic symptoms in the arms and legs were more frequently reported by carriers with and without parents with FXTAS than by controls. Two other studies found a significantly higher prevalence of neuropathic symptoms. Seltzer et al. [7], in a population based sample, reported that $29 \%$ of premutation carriers reported numbness (versus $13 \%$ of controls), and Smith et al. [17] found that $26.6 \%$ of premutation carrier mothers of full mutation children with FXS experienced muscle soreness (versus $16.6 \%$ of controls). Hunter et al. [12] did not find an increase in reporting of musculoskeletal symptoms by 
carrier women compared to controls, although they did not specifically ask about neuropathic symptoms. Based on the literature, it seems that neuropathy is clearly related to carrier status in female carriers but may not become manifest until symptoms of FXTAS also begin to emerge.

\section{Vestibular issues}

Vestibular complaints with a feeling of spinning, suddenly being unbalanced, and difficulty with 'equilibrium' are commonly reported complaints voiced by female premutation carriers. In Chonchaiya et al. [23] dizziness was reported more frequently by carriers with or without a parent with FXTAS than by noncarrier controls, and balance problems by carrier women with a parent with FXTAS more frequently than by carriers with no parent with FXTAS or controls. Smith et al. [17] reported significantly higher rates of dizziness in premutation carrier mothers of children with FXS (5.0\%) than controls (1.3\%), and this was also reported by Seltzer et al. [7] who found that dizziness and faintness were experienced by $18 \%$ of premutation carriers in a population-based sample, significantly higher than controls (4\%). Recent quantitative studies using computerized dynamic posturography (CDP), a 'gold standard' balance assessment tool that has been shown to be highly sensitive, have shown impairments relative to control standards in a small group of female premutation carriers with the vestibular conditions of the sensory organization test and with the motor control and limits of stability test [24]. Vestibular deficits appeared to be present in carriers who did not meet clinical criteria for FXTAS, but were correlated with FXTAS motor rating scale scores and were more severe in those with FXTAS.

\section{Other symptoms}

In addition to the symptoms reported above, Smith et al. [17] reported significantly higher rates of backache and fatigue in premutation carrier mothers of full mutation children with FXS than in controls.
Table 1 summarizes nominations for medical/health features for women with a premutation with and without a diagnosis of FXTAS.

\section{Reproductive features \\ Ovarian insufficiency}

Female premutation carriers are known to be at increased risk for Fragile X-associated Primary Ovarian Insufficiency (FXPOI). FXPOI encompasses premature ovarian failure, or cessation of menses prior to age 40, and other indicators of early ovarian aging or dysfunction [25]. On average, the age at menopause among premutation carriers is 5 years earlier than in the general population of women $[5,7,26]$. Smith et al. [17] also reported significantly higher rates of hot flashes or flushes in premutation carriers (15.4\%) than controls (6.9\%). CGG repeat size has been found to be associated with the risk of earlier menopause but in a non-linear manner, with the highest risk for those with mid-range repeats (approximately 70 to 100) $[5,27-30]$.

Among women who are still cycling, hormonal changes associated with FXPOI are noted more often in women with the premutation compared with controls. These include decreased levels of anti-Müllerian hormone (AMH) and increased levels of follicle stimulating hormone (FSH), among others [5,26,29,31-33]. Other signs of early ovarian aging include irregular, shorter or skipped cycles and subfertility $[27,32]$.

\section{Fertility issues}

The most immediate and significant consequence of POI is reduced fertility [27,34]. Given the higher rates of early menopause, difficulty with fertility is significant for women with a premutation. Even among younger women, difficulty getting pregnant has been reported at higher than expected rates among women who are premutation carriers [27]. In a large national survey study of families affected by FX, female premutation carriers reported a significantly higher rate of use of assistive reproductive technology (for example, fertility

Table 1 Medical/health features examined in premutation carriers

\begin{tabular}{|c|c|c|c|}
\hline $\begin{array}{l}\text { Medical/health } \\
\text { features }\end{array}$ & $\begin{array}{c}\text { Strength of evidence-those } \\
\text { with FXTAS }\end{array}$ & $\begin{array}{c}\text { Strength of evidence-asymptomatic } \\
\text { of FXTAS }\end{array}$ & $\begin{array}{c}\text { Strength of evidence - association with } \\
\text { genetic markers }\end{array}$ \\
\hline Thyroid Disease & Probably related & Possibly related & Possible association with CGG repeat length \\
\hline Hypertension & Possibly related & Possibly related & Possible association with CGG repeat length \\
\hline $\begin{array}{l}\text { Fibromyalgia } \\
\text { symptoms }\end{array}$ & Probably related & Possibly related & Possible association with CGG repeat length \\
\hline Migraine & Possibly related & Possibly related & $\begin{array}{c}\text { Not found to be associated with CGG repeat } \\
\text { length }\end{array}$ \\
\hline Neuropathy & Definitely related & Probably related & $\begin{array}{l}\text { Severity related to CGG repeat length after } \\
\text { controlling for } A R\end{array}$ \\
\hline Vestibular difficulties & Probably related & Probably related & Relationship not yet examined \\
\hline
\end{tabular}

FXTAS- fragile X-associated tremor/ataxia syndrome. 
drugs, IVF) before knowing their FMR1 status than is seen in the national occurrence rates [Wheeler, A.C, Bailey D.B., Raspa M., unpublished data]. Similar to the other symptoms of FXPOI, fertility problems appear to be most significant for women in the midrange CGG group [27].

\section{Obstetric and perinatal difficulties}

Despite known challenges with fertility, very little is known regarding potential obstetric or perinatal risks for FMR1 premutation carriers. One study, conducted in Finland, examined pregnancy outcomes in 63 women who were premutation carriers compared to the general obstetric population [35]. The authors of this study found a slightly higher risk for late pregnancy bleeding in the FMR1 premutation, but no other concerns related to the course or outcome of pregnancy. In a large national survey study [Wheeler, A.C, Bailey D.B., Raspa M., unpublished data] a significantly higher rate of reported preeclampsia was found in premutation carrier women than would be expected based on national occurrence rates in the United States. More research is needed to determine whether women with a premutation experience greater pregnancy or birth risks.

\section{Estrogen-deficiency related conditions}

In general, the state of early estrogen deficiency resulting from POI leads to an increased risk for low bone density, earlier onset osteoporosis and bone fractures [36], impaired endothelial function [37], earlier onset of coronary heart disease [38], and increased cardiovascular mortality. Among premutation carriers, lower bone mineral density [39] and osteoporosis [27] is reported at a high frequency than among non-carriers, but not other estrogen deficiency related disorders.

Hypoestrogenism may have behavioral and cognitive consequences as well. Women with an earlier age at menopause are reported to have more anxiety, depression, somatization, sensitivity, hostility, and psychological distress than women with normal ovarian function [40]. Some studies have found suggestive evidence that symptoms of FXPOI may partially explain the increased vulnerability for mood disorders [41] and anxiety and depression [12].

Given the altered hormone profiles and the stress related to being a carrier of the premutation (for example, additional potential stress of having a newborn with FXS), postpartum depression would seem to be of great concern. Very few studies have specifically examined increased risks for PDD in women with a premutation. Wheeler et al. [unpublished data] found that rates of self-reported postpartum depression among women with a premutation were not higher than is found in national occurrence rates. However, among those who had experienced PPD, $41.18 \%$ experienced at least 2 episodes. In a study of 50 women with a premutation who also had children and a history of major depressive disorder, there was a significant increase in risk for PDD among women with more than one child with FXS [42]. Therefore it may be the cumulative stress of having multiple children with FXS that increases risk for PDD, rather than premutation status. More research is needed in this area.

The question of whether or not endogenous or exogenous estrogen (from replacement therapy) is related to indicators of neurocognitive deficit is unresolved (reviewed in [43]). The statistically significant association of reduced Verbal IQ and a crude measure of estrogen status among premutation carriers suggests further studies should be done [44].

Estrogen also plays a role in immune-response and inflammation and has been implicated in the onset of autoimmune disorders [45], a class of disorders reported to be elevated among women who carry the premutation carries as noted above. Lastly, estrogen has been shown to moderate the impact of chronic stress on mood and psychiatric outcomes [46] a role of particular interest given that women with the premutation often experience high levels of stress related to their role as primary caretakers of children with fragile X syndrome and older relatives with FXTAS.

Table 2 summarizes nominations for reproductive features for women with a premutation with and without probable FXPOI.

Table 2 Reproductive features examined in female premutation carriers with and without FXPOI

\begin{tabular}{llll}
\hline Reproductive features & $\begin{array}{l}\text { Strength of evidence - those } \\
\text { with FXPOI }\end{array}$ & $\begin{array}{l}\text { Strength of evidence-those } \\
\text { without FXPOI }\end{array}$ & $\begin{array}{l}\text { Strength of evidence - association } \\
\text { with genetic markers }\end{array}$ \\
\hline Ovarian insufficiency & Definitely related & Definitely related & $\begin{array}{l}\text { Strong evidence of nonlinear associate } \\
\text { with CGG }\end{array}$ \\
$\begin{array}{l}\text { Estrogen-related } \\
\text { conditions }\end{array}$ & Definitely related & $\begin{array}{l}\text { Possibly related } \\
\text { length }\end{array}$ \\
$\begin{array}{l}\text { Fertility issues } \\
\begin{array}{l}\text { Obstetric and perinatal } \\
\text { difficulties }\end{array}\end{array}$ & Definitely related & Definitely related & $\begin{array}{l}\text { Strong evidence of nonlinear associate } \\
\text { with CGG }\end{array}$ \\
Postpartum depression & Possibly related & Possibly related & Relationship not yet examined \\
\hline
\end{tabular}

FXPOI- fragile $\mathrm{X}$-associated primary ovarian insufficiency. 


\section{Neurocognitive features}

Various cognitive domains have been reported to be affected by the premutation even in those without FXTAS. These domains include executive function $[47,48]$, working memory [49], and arithmetic [50]. These deficits can appear even in young individuals and often show a more progressive course in premutation carriers than in the general population. This may be an early sign of the often significant cognitive impairment, primarily in the realm of executive dysfunction that can accompany FXTAS [51]. However, it must be noted that some studies have not found these areas of weakness. Most likely there is a subset of women with the premutation who are more vulnerable to effects of the premutation.

\section{General intelligence}

Several studies have found normal overall cognitive abilities in non-FXTAS female adult premutation carriers who underwent general intelligence tests (most commonly the Wechsler scales) [47,52-56]. A recent study in older female premutation carriers over age 50 also showed normal IQ scores [57]. In contrast, a few reports have documented lower verbal IQ scores among these women compared to female normal controls $[44,58]$ or their male counterparts [59], with CGG repeat length explaining approximately $4 \%$ of the variance of verbal IQ per linear regression [44]. Case studies have shown mixed results as well, with low $[60,61]$ and superior [62] IQ scores both observed in girls with the premutation. Myers and colleagues [63] examined 14 children (7 female) and found a trend towards lower performance IQ, a measure closely related to executive functioning. Arithmetic difficulties have also been reported in females with the premutation $[50,58]$.

\section{Executive function}

Executive function involves the capacity for self-regulation of behavior and attention, and consists of multiple processes including maintaining and updating relevant information in working memory, inhibition of irrelevant information, switching task goals, and performance monitoring [64,65]. Although executive function has been regarded as the primary cognitive domain affected in patients with FXTAS $[50,66]$, several studies of non-FXTAS female premutation carriers in young adulthood and midlife have reported normal scores on widely-used executive functioning tests such as the Wisconsin Card Sorting Test (WCST), Trail Making Test (TMT) and Stroop Color and Word Test [52,54,55,67]. Whereas, in a study involving older female premutation carriers up to 76 years of age (mean age $=41$ ) [47], executive function, as measured by the Behavioral Dyscontrol Scale (BDS) [68], was modulated by premutation CGG repeat length and/or FMRP level after controlling for full- scale IQ scores (FSIQ). By examining event-related brain potentials (ERPs) in older female premutation carriers, Yang et al. [57] found poorer BDS performance correlated with decreased amplitude of the frontal P300. This ERP component is thought to index selective attention and working memory updating processes, which may underlie the executive dysfunction in both males and females with FXTAS $[57,69]$. Thus, executive dysfunction likely presents as a late-onset phenotype affecting non-FXTAS female premutation carriers over age 50 in addition to non-FXTAS premutation males $[48,66]$. It is also worth noting that both of the two studies $[47,57]$ with findings of executive dysfunction have controlled for FSIQ as a covariate.

\section{Attention}

Sustained attention in a visual search task was comparable among non-FXTAS females with the premutation and various control groups [58]. A large sample of females with the premutation had more self-reported attention deficits than controls without a mutation [55]. Attention involved in enumerating 5 to 8 rectangles was shown to be modulated by both premutation CGG repeat length and age [70].

\section{Memory}

Verbal memory generally remains intact in non-FXTAS female premutation carriers $[55,57,58,67]$, but one case study reported substantially impaired verbal memory functions in a 72-year-old old woman [71]. Both immediate and delayed recall of visual memory has been shown to be affected by the premutation CGG repeat length in these carriers [47]. In a functional magnetic resonance imaging (MRI) experiment using a working memory task, carriers of both genders showed reduced frontal activation regardless of FXTAS diagnosis [72]. Interestingly, Yang et al. [57] found impairments in some measures of working memory in non-FXTAS female carriers that were not present in females with FXTAS.

\section{Language issues}

As noted earlier, studies assessing global indices of verbal ability such as verbal IQ, have generally reported that premutation carriers who are not affected by FXTAS exhibit comparable abilities as matched controls or normed references (reviewed in [12]). In contrast, results from the few studies that have assessed functional language (or, the use of language in social contexts, for example, conversational ability) suggest that such language skills may be impacted among premutation carriers. Sterling et al. [73] elicited brief language samples collected from a group of nearly 200 women with the premutation and assessed samples for different types of dysfluencies, including 
incomplete or abandoned utterances, repetitive speech, excessive fillers (for example, um, ah, oh), and revisions to correct or modify a prior utterance. These types of dysfluencies could reflect problems with executive skills such as planning and organization, and can interfere with fluent communication. As such, they may represent clinically meaningful phenotypes. In this study, the rate and types of dysfluencies were compared between women with the premutation and women who were parents of individuals with autism, included to control for the stress of caring for a child with a disability, which the authors hypothesized could impact fluency. Analyses revealed significantly higher rates of all types of dysfluencies among the premutation carrier group (compared to the mothers of children with autism), as well as a significant association with age (increased dysfluencies with greater age). There was no association with CGG repeat length, and other molecular variables were not examined. Losh et al. [74] also reported elevated rates of subtle conversational differences among premutation carrier women, further suggesting that language may be affected in the premutation.

Table 3 summarizes nominations for cognitive features in females with a premutation with and without a diagnosis of FXTAS.

\section{Psychiatric features \\ Affective disorders}

Mood disorders have been a concern in the fragile $\mathrm{X}$ premutation population for over two decades. Initial small studies in women failed to demonstrate meaningful difference between carriers and controls in depressive disorders [52,75]. However, these studies were small, limited by the screening tools and by poor recall. Later, much larger research studies did demonstrate a relationship between the number of CGG repeats and the presence of depression [76] as well as the severity of depressive symptoms [77]. When comparing 93 women with the premutation screened using the strict criteria of the structured clinical interview for the DSM-IV (SCID) to a large national databank, the lifetime prevalence of major depressive disorder was $43.0 \%$ versus $31.9 \%$ [50]. Although Seltzer et al. [7] did not find evidence of elevated prevalence of depressive symptoms in a populationbased sample, and Smith et al. [17] similarly did not report elevated rates of negative affect in premutation carriers than controls. Seltzer et al. [78] reported evidence of higher rates of depressive and anxiety symptoms in premutation carrier mothers of full mutation children with FXS under certain genetic and environmental conditions: mothers who experienced stressful life events in the previous year had higher rates of depression and anxiety if their CGG repeats were in the mid-range of CGG repeats. Dysthymia and bipolar disorder have generally failed to demonstrate significant levels in carriers compared to controls [79].

\section{Autism spectrum disorders}

Because FXS is one of the most common single-gene disorders associated with autism, investigation has been undertaken to determine what risk the carrier state confers. In a screening study of individuals from families with FXS, roughly $14 \%$ of boys and $5 \%$ of girls with the premutation were found to also have an autism spectrum disorder (ASD) [80]. Even among those carriers not diagnosed with ASD, related psychological traits are more common among carriers compared to controls without the premutation. A relatively large body of research has now documented differences among parents and relatives of individuals with autism, constituting a broad autism phenotype, or, a constellation of mild behavioral features that resemble the features of autism in quality but that are more subtly expressed and not typically associated with functional impairment (reviewed in [81]). A recent study examined a broad range of pragmatic language skills as

Table 3 Cognitive features examined in female premutation carriers with and without FXTAS

\begin{tabular}{|c|c|c|c|}
\hline $\begin{array}{l}\text { Cognitive } \\
\text { features }\end{array}$ & $\begin{array}{l}\text { Strength of evidence- those } \\
\text { with FXTAS }\end{array}$ & $\begin{array}{c}\text { Strength of evidence-asymptomatic } \\
\text { of FXTAS }\end{array}$ & $\begin{array}{c}\text { Strength of evidence - association with } \\
\text { genetic markers }\end{array}$ \\
\hline Low IQ & Definitely related & Probably related & Possible association with CGG repeat length \\
\hline $\begin{array}{l}\text { Arithmetic } \\
\text { difficulties }\end{array}$ & Definitely related & Probably related & Possible association with CGG repeat length \\
\hline $\begin{array}{l}\text { Executive } \\
\text { dysfunction }\end{array}$ & Definitely related & Probably related & Probable association with CGG repeat length \\
\hline Attention deficits & Definitely related & Possibly related & Probable association with CGG repeat length \\
\hline Verbal memory & Definitely related & Not likely related & Possible association with CGG repeat length \\
\hline $\begin{array}{l}\text { Verbal working } \\
\text { memory }\end{array}$ & Definitely related & Probably related & Possible association with CGG repeat length \\
\hline Visual memory & Definitely related & Probably related & Possible association with CGG repeat length \\
\hline Language & Definitely related & Probably related & $\begin{array}{l}\text { Not found to be associated with CGG } \\
\text { repeat length }\end{array}$ \\
\hline
\end{tabular}


well as related behavioral features of the broad autism phenotype among women with the premutation, compared with mothers of children with autism, and mothers of typically developing children with no family history of fragile X, autism, or language impairment [74]. In this study, conversational samples from a videotaped semistructured interview were used to assess pragmatic language using the Pragmatic Rating Scale (PRS) [82]. This study replicated previous findings in the autism parent group and also showed that women with the premutation exhibited similarly elevated rates of pragmatic language problems relative to controls. Factor analysis of items on the PRS revealed that premutation carriers committed the same types of pragmatic language violations as parents of individuals with autism. Such similarities in pragmatic language profiles could suggest that the differences between these groups stem from similar underlying factors, supporting a link between FMR1 and autism-related phenotypes in carrier relatives. In support of this possibility, the study also found that premutation carriers displayed elevated rates of personality traits associated with the broad autism phenotype, rigid or inflexible traits and socially reticent dispositions. The presence of broad autism phenotype traits was associated with greater expression of autism symptoms in their children with FXS. Other studies have also found increased rates of both social aloofness [83] and a rigid perfectionism [84] among carrier women. Studies have shown that amygdala dysfunction in viewing social stimuli seen in carriers correlates with clinical findings of social deficits and both FMRP deficits and elevated FMR1 mRNA levels [85].

\section{Anxiety}

The largest and most recent study of life-time mood and anxiety in the premutation population was completed by Bourgeois et al. [79]. In that study, carriers both suffering and not suffering from FXTAS were compared in the prevalence of anxiety disorders to a very large agematched national dataset. In terms of all anxiety disorders, only those suffering from FXTAS demonstrated a higher prevalence. When separated out, this was similarly true for panic disorder, post-traumatic stress disorder and specific phobia. Generalized anxiety disorder and obsessive compulsive disorder failed to demonstrate any difference between carriers and controls. Only social phobia was found to have higher levels in premutation carriers without FXTAS compared to controls. Chronic anxiety has also been associated with radiological signs on MRI; specifically, the higher the anxiety score the smaller the size of the hippocampus in women with the premutation [86].

Other reports have not found high levels of mental health problems; however, differences in measurements (life-time versus state traits, interview versus self-report), age of participants, ascertainment of participants, etcetera, will all play a role in explaining such differences. Irrespective, continued research to identify vulnerable women is essential.

\section{Psychosis}

Psychosis, given its relative rarity in the general population, has been challenging to study in premutation carriers. Initial linkage analysis failed to show a clear relationship of schizophrenia to the FMR1 gene [87]. Prevalence studies have found the overall rate of psychotic disorders to be low [83]. There have, however, been several case reports of combined psychotic illnesses and the premutation, including schizoaffective disorder [88] and a subject with combined schizophrenia and schizoid personality disorder [89]. Interestingly, as opposed to frank psychotic disorders, multiple studies have found increased prevalence of schizotypal personality traits in the carrier population $[83,90]$.

\section{Attention deficit/hyperactivity disorder}

Attention regulation difficulties have been proposed to be a problem in people with the premutation. Notably, when compared with their control siblings, premutation carriers had significantly more issues with attention than their noncarrier siblings [91]. Inattention and impulsivity amongst FMR1 carriers can be problematic through adulthood [55], although hyperactivity was not noted to be increased in prevalence. In an analysis to examine the genetic architecture of ADHD symptoms in families with FXS, it was found that the FMR1 repeat accounts for about $5 \%$ of the variance whereas polygenes account for about $50 \%$ of the residual variance. This suggests that the premutation acts in concert with additional genetic loci to influence the severity of ADHD symptoms [92].

\section{Sleep and related problems}

Sleep issues have recently been studied in carriers, and common measures such as the Pittsburgh Sleep Quality Index and the Insomnia Severity Index have shown significant pathology. These findings may be related to higher rates of Restless Legs Syndrome and sleep apnea, both of which have shown multiple-fold increases in subsets of the premutation population [93,94]. Sleep apnea is common in older carriers with FXTAS. In a study of 229 males and 201 females with the premutation, including 118 with FXTAS and 123 controls, sleep apnea occurred in $31.4 \%$ of carriers with FXTAS, $8.6 \%$ of carriers without FXTAS and in $13.8 \%$ of controls by medical history [93]. These issues may be contributing to the development of significant fatigue, which is a common complaint of adult carriers [95]. 


\section{Stress susceptibility}

Two hypotheses have been advanced to account for elevated psychiatric, cognitive, and somatic symptoms in premutation carriers [96]: first, that such symptoms are a primary biological feature of FMR1 CGG expansions in the premutation range, and second, that such symptoms may be exacerbated by the stress associated with parenting a child with FXS. Importantly, stress may interact with the biological vulnerabilities caused by the premutation, and thus it is important to incorporate biological markers when exploring stress effects in this population.

Parenting stress It has been well established that many individuals with FXS have severe behavior problems, including inattention, hyperactivity, aggression, anxiety, and autism symptoms [97], which result in high levels of stress exposure for their families [96,98-102]. In one study, exposure to child behavior problems was investigated in the context of a biomarker of the premutation, namely the activation ratio. Hartley et al. [103] studied the prevalence of daily behavior problems in adolescents and adults with FXS who were living with their families, and found that during an 8-day period, 85.7\% exhibited at least one episode of significant behavior problems, such as behaviors that were disruptive, aggressive, destructive, self-injurious, unusual or repetitive, socially offensive, uncooperative, or inattentive. Such episodes occurred, on average, about every other day.

The effects of this level of stress exposure were evident in the mother's level of cortisol, a stress hormone that previously has been shown to be depressed in mothers of children with developmental disabilities, including autism [104,105]. Hartley et al. [103] found that premutation carrier mothers who had a low activation ratio (AR; that is, a low proportion of cells expressing the normal allele) showed an atypical response to their child's behavior problems. Specifically, for mothers with a low $\mathrm{AR}$, the greater the number of behavior problems manifested by their child the previous day, the lower the mother's cortisol level the next morning, which is an atypical response to acute stress. In contrast, for mothers with a high AR (that is, a larger proportion of cells expressing the normal allele), the greater the number of child behavior problems the previous day, the higher the mother's morning cortisol, which is a more normative neuroendocrine response to environmental stress. Also, mothers who had more than one child with FXS had lower cortisol levels than those who had 'only' one affected child, further supporting the toll that stressful parenting takes on neuroendocrine functioning in carrier mothers.

Hunter et al. [106] hypothesized that among women with the premutation, the stress of raising a child with
FXS may be moderated by genetic factors influencing endogenous cortisol responses, which could in turn modulate mental health symptoms. They examined the association of genetic variation in the corticotrophin releasing hormone receptor 1 locus (CRHR1) in 460 women, including premutation carriers with and those without a child with FXS and non-carriers. A statistically significant interaction between the CRHR1 genotype and the status of raising a child with FXS was associated with social anxiety symptoms as reported on the Social Phobia and Anxiety Inventory (SPAI). These preliminary data suggest that there may be a subgroup of premutation carriers who are more susceptible to the effects of stress.

Stressful life events Stressful life events are a source of stress quite distinct from child behavior problems, and include experiences such as divorce, death of a family member or close friend, caring for an aging parent, or negative changes in financial or health status. These life events have been shown to compromise psychological well-being in the general population [107] and in parents of children with developmental disabilities [108,109]. Although exposure to child-related stress is a common characteristic of premutation carrier mothers of children with FXS, these mothers vary with respect to their exposure to other types of stress.

Only one study has been conducted investigating general life stress effects in premutation carrier mothers of children with FXS. Seltzer et al. [78] found that during the previous year, two-thirds (68.3\%) reported having experienced at least one negative life event. However, the other mothers did not experience any of these sources of life stress during the previous year. The variation in exposure to life events made it possible to investigate the effect of exposure to this type of stress on premutation carrier mothers of children with FXS.

Specifically, Seltzer et al. [88] investigated the effects of exposure to stressful life events with respect to depressive and anxiety symptoms as well as cortisol level in premutation carrier mothers. They found that the higher number of stressful life events experienced during the previous year, the greater the level of depression and anxiety, and the lower the level of cortisol. However, variation in the biology of the premutation was critical to understanding the pattern of stress effects. A curvilinear association was observed between stress exposure and CGG repeat length. Premutation carrier mothers with mid-range CGG repeat lengths (approximately 90 to 105) had the highest levels of depression, anxiety, and the most abnormal cortisol parameters if they had recently experienced stressful life events, but mothers in the same CGG repeat range had the lowest level of depression and anxiety, and the most normal cortisol parameters if their life had been free from stressful events 
in the previous year. This divergence was most prominent in the mid-CGG range, whereas those with low CGG repeat numbers or repeats closer to the full mutation cut-off were less reactive to stress. A curvilinear pattern of vulnerability in CGG repeat effects has been previously shown for reproductive outcomes in carrier females [5,26,27] and for depression [56]. This study implicates exposure to stressful life events and CGG repeat length in the manifestation of psychiatric symptoms in premutation carrier mothers.

A large number of studies have shown that autism is an extremely stressful developmental disorder, arguably the disorder posing the greatest level of parenting stress $[110,111]$. A few studies have contrasted parenting stress in mothers who have a child with autism and mothers whose child has FXS [17,112]. These studies generally have found similar patterns for premutation carrier mothers of children with FXS and mothers of those with autism. These findings of similarity between premutation carrier mothers of children with FXS and mothers of children with autism are similar to earlier work in which it was found that the most consistent predictor of maternal depression across disability groups (FXS, ASD, and Down syndrome) was child behavior problems [113]. Only when research that separates the effects of the biology of FMR1 expansions from the effects of stressful parenting will there be a complete understanding of the premutation phenotype and how stress may alter it.

Table 4 summarizes nominations for psychiatric features in premutation carriers.

\section{Conclusions}

At this point there is strong evidence to suggest that females with an FMR1 premutation may be variably at risk for multiple medical, reproductive, cognitive, and psychiatric difficulties. While there are clear phenotypes associated with specific FMR1-related diagnoses (FXS, FXTAS, FXPOI), there are many more diagnoses that may be associated with the premutation and should be considered whenever a premutation carrier presents to a clinic. Several recent papers have described significance and breadth of concerning features reported to be associated with the FMR1 premutation [6,11,114,115], thus capturing the importance of better describing phenotypes associated with the premutation.

Based on this review of the literature, we have identified specific features thought to be at higher risk for premutation carriers as being 'definitely related' 'probably related' 'possibly related' or 'not likely related' to the molecular changes associated with an FMR1 expansion. While the rates of many medical and psychiatric problems are significantly increased in aging carriers who have FXTAS [79], the onset of some of these problems has been reported well before the onset of an official diagnosis [116]. The emergence of some problems, such as ADHD, anxiety disorders and autism traits are noted to occur in some premutation carriers in childhood $[91,117,118]$. However, little is known about the early developmental phenotype of individuals with a premutation, and those studies that have focused on features in children with a premutation are virtually all based on clinically referred children or siblings of an individual with FXS. Additional longitudinal studies are needed to determine at what point some of these features may develop, whether they are developmental or degenerative and what protective factors might reduce risks for more negative outcomes.

CGG repeat length has been implicated in the onset and severity of several of these features. This is most notable in the literature on FXPOI, with a nonlinear association (greater severity among those with midrange repeats) being reported in multiple studies [5,27,28,30]. Similar nonlinear findings have been reported for psychiatric $[12,56,78,119]$ symptoms, while other studies report linear associations between repeat length and severity of neurological symptoms $[22,49,120]$. There may be a variable degree of RNA toxicity in carriers due to elevation of the FMR1 mRNA, which can lead to oxidative stress and neuronal hyperexcitability [121]. FMR1 mRNA level increases with the length of the CGG repeat, and the expanded repeat-containing mRNA makes hairpin loop structures that appear to sequester important proteins for neuronal function including Sam 68, DROSHA and DGCR8 $[122,123]$. These later two proteins are necessary for

Table 4 Psychiatric features examined in female premutation carriers with and without FXTAS

\begin{tabular}{lccc}
\hline $\begin{array}{l}\text { Psychiatric } \\
\text { features }\end{array}$ & $\begin{array}{c}\text { Strength of evidence- those } \\
\text { with FXTAS }\end{array}$ & $\begin{array}{c}\text { Strength of evidence-asymptomatic } \\
\text { of FXTAS }\end{array}$ & $\begin{array}{c}\text { Strength of evidence - association with } \\
\text { genetic markers }\end{array}$ \\
\hline Affective disorders & Probably related & $\begin{array}{c}\text { Probably related } \\
\text { Pnxiety }\end{array}$ & Possibly related \\
Autism traits & Not examined & Possibly related & Possible association with mRNA, CGG repeat length \\
Psychosis & Possibly related & Possibly related & Possible association with mRNA, CGG repeat length \\
ADHD & Possible related & Probably related & Possible association with mRNA, CGG repeat length \\
Sleep issues & Possibly related & Possibly related & Possible association with mRNA, CGG repeat length \\
\hline
\end{tabular}

FXTAS- fragile $\mathrm{X}$-associated tremor/ataxia syndrome. 
maturing the miRNA, which regulate both transcription and translation in the CNS [123]. The RNA toxicity is thought to be related to miRNA dysregulation which can jeopardize survival of the neuron and glia containing the premutation $[124,125]$. Additional research is needed to examine the relationship between these biomarkers and phenotypic features.

Also, cumulative effects of multiple risk factors may occur. Those individuals with the premutation and either intellectual disabilities, seizures or autism traits are also likely to have a second genetic hit [R Lozano, RH, and $\mathrm{F}$ Tassone, unpublished data]. Hypertension and hypothyroidism, irrespective of the strength of the association with the premutation, should be evaluated medically and if present, treated, since the lack of treatment may aggravate CNS dysfunction. Neurological problems including migraines, neuropathy, sleep apnea and psychiatric problems should be considered and if present and sufficiently symptomatic then treatment should be initiated. Exercise, stress reduction techniques such as therapy, biofeedback or meditation, avoidance of toxins, such as excessive alcohol use or illicit drugs, avoidance of vitamin deficiency and healthy eating should be recommended for all carriers [6].

It is important to note that almost all research describing the premutation carrier phenotype is based on individuals who were 'reverse-ascertained' from a child with the full mutation in a clinical setting, and this potentially confounds the effects of the premutation with the impact of stressful parenting and referral bias. Thus, the literature may be skewed toward larger repeats, and more serious symptoms, as well as substantial ascertainment bias toward patients and families who are more likely to seek medical care for themselves or their child with FXS, and thus are more likely to have clinical symptoms. Studies of premutation carriers who do not have children with FXS and even who are not aware of their genetic status would make it possible to address a central unanswered question namely whether, in an unbiased sample of individuals with FMR1 CGG expansions (who, for example, are not exposed to stressful parenting, and are not aware of literature related to their genetic status), there are increased risks of clinical or sub-clinical symptoms (neurocognitive, health, and psychiatric) and whether the severity of such symptoms is associated with their FMR1 genotype.

\section{Abbreviations}

ASD: autism spectrum disorder; BDS: behavioral dyscontrol scale; CDP: computerized dynamic posturography; ERPs: event-related brain potentials; FSIQ: full-scale IQ scores; FXPOI: fragile X-associated primary ovarian insufficiency; FXS: fragile X syndrome; FXTAS: fragile $X$-associated tremor/ataxia syndrome; ID: intellectual disability; IMD: immune-mediated disorders; MRI: magnetic resonance imaging; PRS: pragmatic rating scale; SCID: structured clinical interview for the DSM-IV.

\section{Competing interests}

Bailey has received funding from Novartis Pharmaceuticals. Hagerman has received funding from Novartis, Roche, Seaside Therapeutics, Curemark, and Forest for treatment studies in fragile $X$ syndrome or autism. Summers has received funding for research from Seaside Therapeutics, Roche, Novaris, and Marinus Pharmaceuticals.

\section{Authors' contributions}

AW drafted the introduction and conclusion and organized contributions from all authors; EBK contributed sections on neuropathy and vestibular issues; JG, MM, and LS contributed sections on stress responsivity; ML contributed the language and autism sections; MM, SSherman, and LRR contributed the reproductive section; SSummers contributed the psychiatric section; JO and JCY contributed the cognitive section; $\mathrm{RH}$ contributed to the medical section as well as to the introduction and conclusion. All authors read and approved the final manuscript.

\section{Acknowledgements}

We would like to acknowledge the following funding sources for specific authors:

Wheeler and Bailey-Centers for Disease Control and Prevention (CDC),

National Center on Birth Defects and Developmental Disabilities (NCBDDD) under Cooperative Agreement U01DD000231 to the Association of University Centers on Disabilities (AUCD), project RTOI 2010-999-01; and National Institute of Child Health and Human Development Fragile X Center Grant P30-HD003110-40S

Losh - National Institute of Mental Health 1R01MH091131-01A1

Mila and Rodriguez-Revenga - FEDER and Fondo Investigacion Sanitaria PI12/00897

Yang and Olichney- National Institute on Aging grant (R01 AG18442) Hagerman- National Institutes of Health grants R01HD036071, R01AG032115, UL1DE019583, R01AG03119, and a National Center for Research Resources grant UL1RR024116.

Sherman - National Fragile X Foundation and Emory's Genetics Discovery Fund.

\section{Author details}

${ }^{1}$ RTI International, 3040 Cornwallis Road, Research Triangle Park, NC 27709, USA. ${ }^{2}$ Rush Medical Center, 1735 West Harrison Street Suite 718, Chicago, IL 60612, USA. ${ }^{3}$ Waisman Center, University of Wisconsin, 1500 Highland Avenue, Madison, WI 53705, USA. ${ }^{4}$ Northwestern University, 2240 Campus Drive, Evanston, IL 60208-3507, USA. ${ }^{5}$ Biochemistry and Molecular Genetics Department, Hospital Clinic, Villarroel 170, 08036 Barcelona, Spain. ${ }^{6}$ Center for Mind and Brain, University of California-Davis, 1 Shields Avenue, Davis, CA

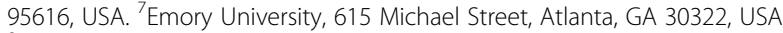
${ }^{8}$ MIND Institute, University of California Davis, 2825 50th Street, Sacramento, CA 95817, USA. ${ }^{9}$ Carolina Institute for Developmental Disabilities, University of North Carolina at Chapel Hill, Chapel Hill, NC 27599, USA.

Received: 16 October 2013 Accepted: 19 March 2014 Published: 30 July 2014

\section{References}

1. Oberlé II, Rousseau FF, Heitz DD, Kretz CC, Devys DD, Hanauer AA, Mandel IL: Instability of a 550-base pair DNA segment and abnormal methylation in fragile X syndrome. Science 1991, 252:1097-1102.

2. Verkerk AJ, Pieretti M, Sutcliffe JS, Fu YH, Kuhl DP, Pizzuti A, Reiner O, Richards S, Victoria MF, Zhang FP, Eussen BE, Van Ommen GJB, Blonden LAJ, Riggins GJ, Chastain JL, Kunst CB, Galjaard H, Caskey CT, Nelson DL, Oostra BA, Warren ST: Identification of a gene (FMR-1) containing a CGG repeat coincident with a breakpoint cluster region exhibiting length variation in fragile X syndrome. Cell 1991, 65:905-914.

3. Yu S, Pritchard M, Kremer E, Lynch M, Nancarrow J, Baker E, Holman K, Mulley JC, Warren ST, Schlessinger D, Sutherland GR, Richards RI: Fragile X genotype characterized by an unstable region of DNA. Science 1991, 252:1179-1181.

4. Spector EB: Fragile X - A Family of Disorders: Changing Phenotype and Molecular Genetics. In The Principles of Clinical Cytogenetics. New York: Springer; 2013:453-471 
5. Sullivan AK, Marcus M, Epstein MP, Allen EG, Anido AE, Paquin JJ, Sherman SL: Association of FMR1 repeat size with ovarian dysfunction. Hum Reprod 2005, 20:402-412.

6. Hagerman RJ, Hagerman PJ: Advances in clinical and molecular understanding of the FMR1 premutation and fragile $\mathrm{X}$-associated tremor/ataxia syndrome. Lancet Neurol 2013, 12:786-798.

7. Seltzer MM, Baker MW, Hong J, Maenner M, Greenberg J, Mandel D: Prevalence of CGG expansions of the FMR1 gene in a US population-based sample. Am J Med Genet B Neuropsychiatr Genet 2012, 159B:589-597.

8. Tassone F, Long K, Tong T, Lo J, Gane LW, Berry-Kravis E, Nguyen D, Mu LM, Laffin J, Bailey DB, Hagerman RJ: FMR1 CGG allele size and prevalence ascertained through newborn screening in the United States. Genome Med 2012, 4:100.

9. Maenner M, Baker M, Broman K, Tian J, Barnes J, Atkins A, McPherson E, Hong J, Brilliant M, Mailick M: FMR1 CGG expansions: Prevalence and sex ratios. Am J Med Genet B Neuropsychiatr Genet 2013, 162B:466-473.

10. Coffey SM, Cook K, Tartaglia N, Tassone F, Nguyen DV, Pan R, Bronsky HE, Yuhas J, Borodyanskaya M, Grigsby J, Doerflinger M, Hagerman PJ, Hagerman RJ: Expanded clinical phenotype of women with the FMR1 premutation. Am J Med Genet Part A 2008, 146A:1009-1016.

11. Rodriguez-Revenga L, Madrigal I, Pagonabarraga J, Xunclà M, Badenas C, Kulisevsky J, Gomez B, Milà M: Penetrance of FMR1 premutation associated pathologies in fragile X syndrome families. Eur J Hum Genet 2009, 17:1359-1362.

12. Hunter JE, Rohr JK, Sherman SL: Co-occurring diagnoses among FMR1 premutation allele carriers. Clin Genet 2010, 77:374-381.

13. Winarni TI, Chonchaiya W, Sumekar TA, Ashwood P, Morales GM, Tassone F, Nguyen DV, Faradz SMH, Van de Water J, Cook K, Hamlin A, Mu Y, Hagerman PJ, Hagerman RJ: Immune-mediated disorders among women carriers of fragile X premutation alleles. Am J Med Genet 2012, 158A:2473-2481.

14. Martorell L, Tondo M, Garcia-Fructuoso F, Naudo M, Alegre C, Gamez J, Poo P: Screening for the presence of FMR1 premutation alleles in a Spanish population with fibromyalgia. Clin Rheumatol 2012, 31:1611-1615.

15. Rodríguez-Revenga L, Madrigal I, Blanch-Rubio J, Elurbe DM, Doscampo E, Collado A, Vidal J, Corbonell J, Estivill X, Milla M: Screening for the presence of FMR1 premutation alleles in women with fibromyalgia. Gene 2013, 512:305-308.

16. Au J, Akins RS, Berkowitz-Sutherland L, Tang HT, Chen Y, Boyd A, Hagerman R: Prevalence and risk of migraine headaches in adult fragile $X$ premutation carriers. Clin Genet 2013, 84:546-51.

17. Smith LE, Barker ET, Seltzer MM, Abbeduto L, Greenberg JS: Behavioral phenotype of fragile $X$ syndrome in adolescence and adulthood. Am J Intellect Dev Disabil 2013, 117:1-17.

18. Ross-Inta C, Omanska-Klusek A, Wong S, Barrow C, Garcia-Arocena D, Iwahashi C, Giulivi C: Evidence of mitochondrial dysfunction in fragile X-associated tremor/ataxia syndrome. Biochem J 2010, 429:545-552.

19. Napoli E, Ross-Inta C, Wong S, Hung C, Fujisawa Y, Sakaguchi D, Giulivi C: Mitochondrial dysfunction in Pten haplo-insufficient mice with social deficits and repetitive behavior: interplay between Pten and p53. PloS One 2012, 7(8):e42504. doi:10.1371/journal.pone.0042504.

20. Hagerman RJ, Leavitt BR, Farzin F, Jacquemont S, Greco CM, Brunberg JA, Tassone F, Hessl D, Harris SW, Zhang L, Jardini T, Gane LW, Ferranti LJ, Ruiz L, Leehey MA, Grigsby J, Hagerman PJ: Fragile-X-associated tremor/ataxia syndrome (FXTAS) in females with the FMR1 premutation. Am J Hum Genet 2004, 74:1051-1056.

21. Tassone F, Greco CM, Hunsaker MR, Seritan AL, Berman RF, Gane LW, Jacquemont S, Basuta K, Jin LW, Hagerman PJ, Hagerman RJ: Neuropathological, clinical and molecular pathology in female fragile $X$ premutation carriers with and without FXTAS. Genes Brain Behav 2012, 11:577-585.

22. Berry-Kravis E, Goetz CG, Leehey M, Hagerman R, Zhang L, Li L, Nguyen D, Hall D, Tartaglia N, Cogswell J, Tassone F, Hagerman P: Neuropathic features in fragile X premutation carriers. Am J Med Genet 2007, 143:19-26.

23. Chonchaiya W, Nguyen DV, Au J, Campos L, Berry-Kravis EM, Lohse K, Mu Y, Utari A, Hervey C, Wang L, Sorensen P, Cook K, Gane L, Tassone F, Hagerman RJ: Clinical involvement in daughters of men with fragile $X$-associated tremor ataxia syndrome. Clin Genet 2010, 78:38-46.

24. O'Keefe J: Proceedings of the International Conference on Fragile X Syndrome: 2012. Miami. Walnut Creek, CA: National Fragile X Foundation; 2012:25.

25. Sullivan SD, Welt C, Sherman S: FMR1 and the continuum of primary ovarian insufficiency. Semin Reprod Med 2011, 29:299-307.
26. Murray A: Premature ovarian failure and the FMR1 gene. Semin Reprod Med 2000, 18:59-66.

27. Allen EG, Sullivan AK, Marcus M, Small C, Dominguez C, Epstein MP, Sherman SL: Examination of reproductive aging milestones among women who carry the FMR1 premutation. Hum Reprod 2007, 22:2142-2152.

28. Ennis S, Ward D, Murray A: Nonlinear association between CGG repeat number and age of menopause in FMR1 premutation carriers. Eur J Hum Genet 2006, 14:253-255.

29. Spath MA, Feuth TB, Allen EG, Smits APT, Yntema HG, van Kessel AG, Thomas CMG: Intra-individual stability over time of standardized anti-Müllerian hormone in FMR1 premutation carriers. Hum Reprod 2011, 26:2185-2191.

30. Tejada Ml, García-Alegría E, Bilbao A, Martínez-Bouzas C, Beristain E, Poch M, Ramos F: Analysis of the molecular parameters that could predict the risk of manifesting premature ovarian failure in female premutation carriers of fragile X syndrome. Menopause 2008, 15:945-949.

31. Hundscheid RD, Braat DD, Kiemeney LA, Smits AP, Thomas CM: Increased serum FSH in female fragile $X$ premutation carriers with either regular menstrual cycles or on oral contraceptives. Hum Reprod 2001, 16:457-462.

32. Welt CK: Primary ovarian insufficiency: a more accurate term for premature ovarian failure. Clin Endocrinol 2008, 68:499-509.

33. Rohr J, Allen EG, Charen K, Giles J, He W, Dominguez C, Sherman SL: Anti-Mullerian hormone indicates early ovarian decline in fragile $X$ mental retardation (FMR1) premutation carriers: a preliminary study. Hum Reprod 2008, 23:1220-1225.

34. Streuli I, Fraisse T, Ibecheole V, Moix I, Morris MA, de ZD: Intermediate and premutation FMR1 alleles in women with occult primary ovarian insufficiency. Fertil Steril 2009, 92:464-470.

35. Kallinen J, Korhonen K, Kortelainen S, Heinonen S, Ryynänen M: Pregnancy outcome in carriers of fragile X. BJOG 2000, 107:969-972.

36. Gallagher JC: Effect of early menopause on bone mineral density and fractures. Menopause 2007, 14:567-571.

37. Kalantaridou SN, Naka KK, Papanikolaou E, Kazakos N, Kravariti M, Calis KA, Paraskevaidis EA, Sideris DA, Tsatsoulis A, Chrousos GP, Michalis LK: Impaired endothelial function in young women with premature ovarian failure: normalization with hormone therapy. J Clin Endocrinol Metab 2004, 89:3907-3913

38. Atsma F, Bartelink ML, Grobbee DE, van der Schouw YT: Postmenopausal status and early menopause as independent risk factors for cardiovascular disease: a meta-analysis. Menopause 2006, 13:265-279.

39. Hundscheid RDL, Smits APT, Thomas CMG, Kiemeney LALM, Braat DD: Female carriers of fragile $X$ premutations have no increased risk for additional diseases other than premature ovarian failure. Am J Med Genet A 2003, 117:6-9.

40. Mondul AM, Rodriguez C, Jacobs EJ, Calle EE: Age at natural menopause and cause-specific mortality. Am J Epidemiol 2005, 162:1089-1097.

41. Rodriguez-Revenga L, Madrigal I, Alegret M, Santos M, Milà M: Evidence of depressive symptoms in fragile- $X$ syndrome premutated females. Psychiatr Genet 2008, 18:153-155.

42. Obadia W, losif AM, Seritan A: Postpartum Depression in Women with the FMR1 Premutation. Curr Psychiatr Rev 2013, 9:72-77.

43. Janicki SC, Schupf N: Hormonal influences on cognition and risk for Alzheimer's disease. Curr Neurol Neurosci Rep 2010, 10:359-366.

44. Allen EG, Sherman S, Abramowitz A, Leslie M, Novak G, Rusin M, Scott E, Letz R: Examination of the effect of the polymorphic CGG repeat in the FMR1 gene on cognitive performance. Behav Genet 2005, 35:435-445.

45. Walker SE: Estrogen and autoimmune disease. Clin Rev Allergy Immunol 2011, 40:60-65.

46. Alexander JL, Dennerstein L, Woods NF, Kotz K, Halbreich U, Burt V, Richardson G: Neurobehavioral impact of menopause on mood. Expert Rev Neurother 2007, 7:S81-S91.

47. Loesch DZ, Bui QM, Grigsby J, Butler E, Epstein J, Huggins RM, Hagerman R: Effect of the fragile $X$ status categories and the fragile $X$ mental retardation protein levels on executive functioning in males and females with fragile X. Neuropsychology 2003, 17:646-657.

48. Grigsby J, Brega AG, Engle K, Leehey MA, Hagerman RJ, Tassone F, Hessl D, Hagerman PJ, Cogswell JB, Bennett RE, Cook K, Hall DA, Bounds LS, Paulich MJ, Reynolds A: Cognitive profile of fragile $X$ premutation carriers with and without fragile $\mathrm{X}$-associated tremor/ataxia syndrome. Neuropsychology 2008, 22:48-60.

49. Cornish KM, Li L, Kogan CS, Jacquemont S, Turk J, Dalton A, Hagerman PJ: Age-dependent cognitive changes in carriers of the fragile $X$ syndrome. Cortex 2008, 44:628-636. 
50. Lachiewicz AM, Dawson DV, Spiridigliozzi GA, McConkie-Rosell A: Arithmetic difficulties in females with the fragile X premutation. Am J Med Genet A 2006, 140:665-672

51. Grigsby J, Brega AG, Jacquemont S, Loesch DZ, Leehey MA, Goodrich GK, Hagerman PJ: Impairment in the cognitive functioning of men with fragile X-associated tremor/ataxia syndrome (FXTAS). J Neurol Sci 2006, 248:227-233.

52. Reiss AL, Freund L, Abrams MT, Boehm C, Kazazian H: Neurobehavioral effects of the fragile $X$ premutation in adult women: a controlled study. Am J Hum Genet 1993, 52:884-894.

53. Riddle JE, Cheema A, Sobesky WE, Gardner SC, Taylor AK, Pennington BF, Hagerman RJ: Phenotypic involvement in females with the FMR1 gene mutation. Am J Ment Retard 1998, 102:590-601.

54. Bennetto L, Pennington BF, Porter D, Taylor AK, Hagerman RJ: Profile of cognitive functioning in women with the fragile $\mathrm{X}$ mutation. Neuropsychology 2001, 15:290-299.

55. Hunter JE, Allen EG, Abramowitz A, Rusin M, Leslie M, Novak G, Sherman SL: No evidence for a difference in neuropsychological profile among carriers and noncarriers of the FMR1 premutation in adults under the age of 50. Am J Hum Genet 2008, 83:692-702.

56. Roberts JE, Bailey DB Jr, Mankowski J, Ford A, Sideris J, Weisenfeld LA, Golden RN: Mood and anxiety disorders in females with the FMR1 premutation. Am J Med Genet B 2009, 150:130-139.

57. Yang JC, Simon C, Niu YQ, Bogost M, Schneider A, Tassone F, Seritan A, Grigsby J, Hagerman PJ: Hagerman RJ. Phenotypes of hypofrontality in older female fragile x premutation carriers. Ann Neurol: Olichney JM; 2013. doi:10.1002/ana.23933

58. Franke $\mathrm{P}$, Leboyer M, Hardt J, Sohne E, Weiffenbach O, Biancalana W, Cornillet-Lefebre P, Delobel B, Froster U, Schwab SG, Poustka F, Hautzinger M, Maier W: Neuropsychological profiles of FMR-1 premutation and full-mutation carrier females. Psychiatry Res 1999, 87:223-231.

59. Adams JS, Adams PE, Nguyen D, Brunberg JA, Tassone F, Zhang W, Koldewyn K, Rivera SM, Grigsby J, Zhang L, DeCarli C, Hagerman PJ, Hagerman RJ: Volumetric brain changes in females with fragile X-associated tremor/ataxia syndrome (FXTAS). Neurology 2007, 69:851-859.

60. Tassone F, Hagerman RJ, Taylor AK, Mills JB, Harris SW, Gane LW, Hagerman PJ: Clinical involvement and protein expression in individuals with the FMR1 premutation. Am J Med Genet 2000, 91:144-152.

61. Wirojanan J, Angkustsiri K, Tassone F, Gane LW, Hagerman RJ: A girl with fragile X premutation from sperm donation. Am J Med Genet A 2008, 146:888-892.

62. Basuta K, Narcisa V, Chavez A, Kumar M, Gane L, Hagerman R, Tassone F: Clinical phenotypes of a juvenile sibling pair carrying the fragile $X$ premutation. Am J Med Genet A 2011, 155A:519-525.

63. Myers GF, Mazzocco MM, Maddalena A, Reiss AL: No widespread psychological effect of the fragile $X$ premutation in childhood: evidence from a preliminary controlled study. J Dev Behav Pediatr 2001, 22:353-359.

64. Miyake A, Friedman NP, Emerson MJ, Witzki AH, Howerter A, Wager TD: The unity and diversity of executive functions and their contributions to complex "Frontal Lobe" tasks: a latent variable analysis. Cogn Psychol 2000, 41:49-100

65. Gilbert SJ, Burgess PW: Executive function. Curr Biol 2008, 18:R110-R114.

66. Brega AG, Goodrich G, Bennett RE, Hessl D, Engle K, Leehey MA, Bounds LS, Paulich MJ, Hagerman RJ, Hagerman PJ, Cogswell JB, Tassone F, Reynolds A, Kooken $\mathrm{R}$, Kenny M, Grigsby J: The primary cognitive deficit among males with fragile X-associated tremor/ataxia syndrome (FXTAS) is a dysexecutive syndrome. J Clin Exp Neuropsychol 2008, 30:853-869.

67. Thompson NM, Gulley ML, Rogeness GA, Clayton RJ, Johnson C, Hazelton B, Cho CG, Zellmer VT: Neurobehavioral characteristics of CGG amplification status in fragile X females. Am J Med Genet 1994, 54:378-383.

68. Grigsby J, Kaye K: The Behavioral Dyscontrol Scale: Manual. 2nd edition. Denver: BDS; 1996

69. Yang JC, Chan SH, Khan S, Schneider A, Nanakul R, Teichholtz S, Niu Y-Q, Seritan A, Tassone F, Grigsby J, Hagerman PJ, Hagerman RJ, Olichney JM: Neural substrates of executive dysfunction in fragile $X$-associated tremor/ataxia syndrome (FXTAS): a brain potential study. Cereb Cortex 2012, 23:2657-2666.

70. Goodrich-Hunsaker NJ, Wong LM, McLennan Y, Tassone F, Harvey D, Rivera SM, Simon TJ: Adult female fragile $X$ premutation carriers exhibit Age- and CGG repeat length-related impairments on an attentionally based enumeration task. Front Hum Neurosci 2011, 5:63.
71. Al-Hinti JT, Nagan N, Harik SI: Fragile X premutation in a woman with cognitive impairment, tremor, and history of premature ovarian failure. Alzheimer Dis Assoc Disord 2007, 21:262-264.

72. Hashimoto R, Backer KC, Tassone F, Hagerman RJ, Rivera SM: An fMRI study of the prefrontal activity during the performance of a working memory task in premutation carriers of the fragile $X$ mental retardation 1 gene with and without fragile X-associated tremor/ataxia syndrome (FXTAS). J Psychiatr Res 2011, 45:36-43.

73. Sterling AM, Mailick M, Greenberg J, Warren SF, Brady N: Language dysfluencies in females with the FMR1 premutation. Brain Cogn 2013, 82:84-80.

74. Losh M, Klusek J, Martin GE, Sideris J, Parlier M, Piven J: Defining genetically meaningful language and personality traits in relatives of individuals with fragile $X$ syndrome and relatives of individuals with autism. Am J Med Genet B 2012, 159B:660-668.

75. Sobesky WE, Pennington BF, Porter D, Hull CE, Hagerman RJ: Emotional and neurocognitive deficits in fragile X. Am J Med Genet 1994, 51:378-385.

76. Johnston C, Eliez S, Dyer-Friedman J, Hessl D, Glaser B, Blasey C, Reiss A: Neurobehavioral phenotype in carriers of the fragile $\mathrm{X}$ premutation. $\mathrm{Am}$ J Med Genet 2001, 103:314-319.

77. Hunter JE, Allen EG, Abramowitz A, Rusin M, Leslie M, Novak G, Sherman SL: Investigation of phenotypes associated with mood and anxiety among male and female fragile X premutation carriers. Behav Genet 2008, 38:493-502.

78. Seltzer MM, Barker ET, Greenberg JS, Hong J, Coe C, Almeida D: Differential sensitivity to life stress in FMR1 premutation carrier mothers of children with fragile X syndrome. Health Psychol 2012, 31:612-622.

79. Bourgeois JA, Coffey SM, Rivera SM, Hessl D, Gane LW, Tassone F, Greco C, Finucane B, Nelson L, Berry-Kravis E, Grigsby J, Hagerman PJ, Hagerman RJ: A review of fragile $X$ premutation disorders: Expanding the psychiatric perspective. J Clin Psychiatry 2009, 70:852-862.

80. Clifford S, Dissanayake C, Bui QM, Huggins R, Taylor AK, Loesch DZ: Autism spectrum phenotype in males and females with fragile $X$ full mutation and premutation. J Autism Dev Disord 2007, 37:738-747.

81. Losh M, Adolphs R, Piven J: The Broad Autism Phenotype. In Autism Spectrum Disorders. Edited by Dawson G, Amaral D, Geschwind D. Oxford: Oxford University Press; 2011:457-476.

82. Landa R, Piven J, Wzorek MM, Gayle JO, Chase GA, Folstein SE: Social language use in parents of autistic individuals. Psychol Med 1992, 22:245-254.

83. Franke $P$, Leboyer $M$, Gansicke $M$, Weiffenbach $O$, Biancalana V, Cornillet-Lefebre P, Maier W: Genotype-phenotype relationship in female carriers of the premutation and full mutation of FMR-1. Psychiatry Res 1998, 80:113-127.

84. Hessl D, Rivera SM, Reiss AL: The neuroanatomy and neuroendocrinology of fragile X syndrome. Ment Retard Dev D R 2004, 10:17-24.

85. Hessl D, Wang JM, Schneider A, Koldewyn K, Le L, Iwahashi C, Rivera SM: Decreased fragile $X$ mental retardation protein expression underlies amygdala dysfunction in carriers of the fragile $X$ premutation. Biol Psychiatry 2011, 70:859-865.

86. Adams PE, Adams JS, Nguyen DV, Hessl D, Brunberg JA, Tassone F, Zhang W, Koldewyn K, Rivera SM, Grigsby J, Zhang L, DeCarli C, Hagerman PJ, Hagerman RJ: Psychological symptoms correlate with reduced Hippocampal volume in fragile X premutation carriers. Am J Med Genet Part B 2010, 153B:775-785.

87. Ashworth A, Abusaad I, Walsh C, Nanko S, Murray RM, Asherson P, Collier DA: Linkage analysis of the fragile $X$ gene FMR-1 and schizophrenia: no evidence for linkage but report of a family with schizophrenia and an unstable triplet repeat. Psychiatr Genet 1996, 6:81-86.

88. Al-Semaan Y, Malla AK, Lazosky A: Schizoaffective disorder in a fragile-X carrier. Aust N Z J Psychiatry 1999, 33:436-440.

89. Khin NA, Tarleton J, Raghu B, Park SK: Clinical description of an adult male with psychosis who showed FMR1 gene methylation mosaicism. Am J Med Genet 1998, 81:222-224.

90. Thompson NM, Rogeness GA, McClure E, Clayton R, Johnson C: Influence of depression on cognitive functioning in Fragile $\mathbf{X}$ females. Psychiatry Res 1996, 64:97-104.

91. Bailey DB Jr, Raspa M, Olmsted M, Holiday DB: Co-occurring conditions associated with FMR1 gene variations: Findings from a national parent survey. Am J Med Genet 2008, 146a:2060-2069.

92. Hunter JE, Epstein MP, Tinker SW, Abramowitz A, Sherman SL: The FMR1 premutation and attention-deficit hyperactivity disorder (ADHD): evidence for a complex inheritance. Behav Genet 2012, 42:415-422. 
93. Hamlin A, Liu Y, Nguyen DV, Tassone F, Zhang L, Hagerman RJ: Sleep apnea in fragile $X$ premutation carriers with and without FXTAS. Am $J$ Med Genet B Neuropsychiatr Genet 2011, 156b:923-928.

94. Summers SM, Cogswell J, Goodrich JE, Mu Y, Nguyen DV, Brass SD, Hagerman RJ: Prevalence of restless legs syndrome and sleep quality in carriers of the fragile x premutation. Clin Genet 2013. in press.

95. Summers SM, Cogswell J, Goodrich JE, Mu Y, Nguyen DV, Brass SD, Hagerman RJ: Fatigue and Body Mass Index in the Fragile X Premutation Carrier. Fatigue: Biomedicine, Health \& Behavior 2014. 10.1080/ 21641846.2014.881155, 2014.

96. Bailey DB, Sideris J, Roberts J, Hatton D: Child and genetic variables associated with maternal adaptation to fragile $\mathrm{X}$ syndrome: $\mathrm{A}$ multidimensional analysis. Am J Med Genet A 2008, 146:720-729.

97. Hagerman RJ: Clinical and molecular aspects of fragile $x$ syndrome. In Neurodevelopmental Disorders. Edited by Tager-Fluberg H. Massachusetts: Massachusetts Institute of Technology; 1999:27-42.

98. Franke P, Maier W, Hautzinger M, Weiffenbach O, Gansicke M, Iwers B, Froster U: Fragile-X carrier females: Evidence for a distinct psychopathological phenotype? Am J Med Genet 1996, 64:334-339.

99. Johnston C, Hessel D, Blasey C, Eliez S, Erba H, Dyer-Friedman J, Reiss AL: Factors associated with parenting stress in mothers of children with fragile X syndrome. J Dev Behav Pediat 2003, 24:267-275.

100. Sarimski K: Behavioural phenotypes and family stress in three mental retardation syndromes. Eur Child Adoles Psy 1997, 6:26-31.

101. Lieshout CFV, De Meyer RE, Curfs LM, Fryns JP: Family contexts, parental behaviour, and personality profiles of children and adolescents with prader-willi, fragile-X, or Williams syndrome. Child Psychol Psych 1998, 39:699-710.

102. von Gontard A, Backes M, Laufersweiler-Plass C, Wendland C, Lehmkuhl G, Zerres K, Rudnik-Schoneborn S: Psychopathology and family stress comparison of boys with fragile X syndrome and Spinal Muscular Atrophy. Child Psychol Psych 2002, 43:949-957.

103. Hartley S, Seltzer MM, Hong J, Greenberg J, Smith L, Almeida D, Coe C, Abbeduto L: Cortisol response to behavior problems in FMR1 premutation mothers of adolescents and adults with fragile $X$ syndrome: A diathesis-stress model. Int J Behav Dev 2012, 36:53-61.

104. Seltzer MM, Almeida DM, Greenberg JS, Savla J, Stawski RS, Hong J, Taylor JL: Psychological and biological markers of daily lives of midlife parents of children with disabilities. J Health Soc Behav 2009, 50:1-15.

105. Seltzer MM, Greenberg JS, Hong J, Smith LE, Almeida DM, Coe C, Stawski RS: Maternal cortisol levels and child behavior problems in families of adolescents and adults with ASD. J Autism Dev Disord 2010, 40:457-469.

106. Hunter JE, Leslie M, Novak G, Hamilton D, Shubeck L, Charen K, Abramowitz A, Epstein MP, Lori A, Binder E, Cubells JF, Sherman SL: Depression and anxiety symptoms among women who carry the FMR1 premutation: impact of raising a child with fragile $X$ syndrome is moderated by CRHR1 polymorphisms. Am J Med Genet B Neuropsychiatr Genet 2012, 59B:549-59.

107. Luhmann M, Hofmann W, Eid M, Lucas RE: Subjective well-being and adaptation to life events: a meta-analysis. J Pers Soc Psychol 2012, 102:592.

108. Barker ET, Hartley SL, Seltzer MM, Floyd FJ, Greenberg JS, Orsmond GI: Trajectories of emotional well-being in mothers of adolescents and adults with autism. Dev Psychol 2011, 47:551-561.

109. Warfield ME, Krauss MW, Hauser-Cram P, Upshur CC, Shonkoff JP: Adaptation during early childhood among mothers of children with disabilities. $J \mathrm{Dev}$ Behav Pediatr 1999, 20:9-16

110. Duarte CS, Bordin IA, Yazigi L, Mooney J: Factors associated with stress in mothers of children with autism. Autism 2005, 9:416-427.

111. Montes G, Halterman JS: Psychological functioning and coping among mothers of children with autism: A population-based study. Pediatrics 2006, 119:1040-1046.

112. Wong JD, Mailick MR, Greenberg J, Coe CL: Daily work stress and awakening cortisol in mothers of individuals with autism spectrum disorders or fragile $\mathrm{X}$ syndrome. In press.

113. Abbeduto L, Seltzer MM, Shattuck P, Krauss MW, Orsmond G, Murphy MM: Psychological well-being and coping in mothers of youth with autism, Down syndrome, or fragile X syndrome. Am J Ment Retard 2004, 109:237-254.

114. Crum-Bailey JM, Dennison DH, Weiner WJ, Hawley JS: The neurology and corresponding genetics of fragile $X$ disorders: insights into the genetics of neurodegeneration. Future Neurol 2013, 8:225-235.
115. Kraan CM, Hocking DR, Bradshaw JL, Fielding J, Cohen J, GeorgiouKaristianis N, Cornish KM: Neurobehavioral evidence for the involvement of the FRM1 gene in female carriers of fragile $X$ syndrome. Neurosci Biobehav Rev 2013, 37:522-547.

116. Seritan L, Bourgeois J, Schneider A, Mu Y, Hagerman R, Nguyen D: Ages of onset of mood and anxiety disorders in fragile $\mathrm{X}$ premutation carriers. Curr Psychiatr Rev 2013, 9:65-71.

117. Chonchaiya W, Au J, Schneider A, Hessl D, Harris SW, Laird M, Hagerman RJ: Increased prevalence of seizures in boys who were probands with the FMR1 premutation and co-morbid autism spectrum disorder. Hum Genet 2012, 131:581-589.

118. Farzin F, Perry H, Hess D, Loesch D, Cohen J, Bacalman S, Hagerman R: Autism spectrum disorders and attention-deficit/hyperactivity disorder in boys with the fragile X premutation. J Dev Behav Pediatr 2006, 27(2 Suppl):S137-144.

119. Loesch DZ, Bui MQ, Hammersley E, Schneider A, Storey E, Stimpson P, Burgess T, Francis D, Slater H, Tassone F, Hagerman RJ, Hessl D: Psychological status in female carriers of premutation FMR1 allele showing a complex relationship with the size of CGG expansion. Clin Genet 2014. doi: 10.1111/cge.12347.

120. Leehey MA, Berry-Kravis E, Goetz CG, Zhang L, Hall DA, Li L, Rice CD, Lara R, Cogswell J, Reynolds A, Gane L, Jacquemont S, Tassone F, Grigsby J, Hagerman RJ, Hagerman PJ: FMR1 CGG repeat length predicts motor dysfunction in premutation carriers. Neurology 2008, 70:1397-1402.

121. Cao Z, Hulsizer S, Tassone F, Tang HT, Hagerman RJ, Rogawski MA, Pessah IN: Clustered burst firing in FMR1 premutation hippocampal neurons: amelioration with allopregnanolone. Hum Mol Genet 2012, 21:2923-2935.

122. Sellier C, Rau F, Liu Y, Tassone F, Hukema RK, Gattoni R, Schneider A, Charlet-Berguerand N: Sam68 sequestration and partial loss of function are associated with splicing alterations in FXTAS patients. EMBO J 2010, 29:1248-1261.

123. Sellier C, Freyermuth F, Tabet R, Tran T, He F, Ruffenach F, Charlet-Berguerand N: Sequestration of DROSHA and DGCR8 by expanded CGG RNA repeats alters microRNA processing in fragile $\mathrm{X}$-associated tremor/ataxia syndrome. Cell Rep 2013, 3:869-880.

124. Chen Y, Zhu X, Zhang X, Liu B, Huang L: Nanoparticles modified with tumor-targeting scFv deliver siRNA and miRNA for cancer therapy. Mol Ther 2010, 18:1650-1656.

125. Hagerman PJ: Fragile X-associated tremor/ataxia syndrome (FXTAS): pathology and mechanisms. Acta Neuropath 2013:1-19.

doi:10.1186/1866-1955-6-30

Cite this article as: Wheeler et al:: Associated features in females with an FMR1 premutation. Journal of Neurodevelopmental Disorders 2014 6:30.

\section{Submit your next manuscript to BioMed Central and take full advantage of:}

- Convenient online submission

- Thorough peer review

- No space constraints or color figure charges

- Immediate publication on acceptance

- Inclusion in PubMed, CAS, Scopus and Google Scholar

- Research which is freely available for redistribution 